\title{
AMALAN PERTUKARAN ASING KONVENSIONAL: ANALISA BERDASARKAN PERSPEKTIF SYARIAH
}

\section{Foreign Exchange in Conventional Banking Industry: An Analysis from Shariah Perspective}

\author{
Abdul Rahman A Shukor ${ }^{1}$ \\ Joni Tamkin Borhan²
}

\begin{abstract}
Foreign exchange is the largest market in the world and operates 24 hours a day. Foreign exchange consists of FX Spot, FX Forward, and FX Swap. Shariah guidelines stipulate that any currency exchange must adhere to the rule of al-sarf whereby the exchange of different currencies must exchanged immediately hand-to-hand. Generally, conventional foreign exchange practice contradicts the requirements of al-sarf because it involves an element of riba. However there are different views from Islamic scholars on the permissibility of these transaction. Therefore, the aim of this study is to analyse these foreign exchange transactions from a Shariah perspective. The result of this study shows that
\end{abstract}

1 Ph.D Candidate, Department of Shariah and Economy, Academy of Islamic Studies, University of Malaya, 50603 Kuala Lumpur and Head of Shariah Advisory, Shariah Division, Al Rajhi Bank (Malaysia) Berhad, 50450 Kuala Lumpur,misyaki20@hotmail.com

2 Professor, Department of Shariah and Economy, Academy of Islamic Studies, University of Malaya, 50603 Kuala Lumpur, joni@um.edu.my 
FX Spot complies with Shariah guidelines when subject to the requirements of al-sarf. Meanwhile FX Forward and FX Swap are outside the bounds of these guidelines.

Keywords: foreign exchange, forex, FX Spot, FX Forward, FX Swap

\section{PENDAHULUAN}

Pertukaran asing ialah pasar borong bagi aktiviti penjualan dan pembelian mata wang asing. Aktiviti ini merangkumi pembelian mata wang asing oleh pengimport untuk menjelaskan bayaran import dan bagi pengeksport yang perlu menukarkan perolehan eksport daripada wang asing kepada wang tempatan. ${ }^{3}$ Urus niaga pertukaran asing melibatkan mata wang tempatan dengan mata wang negara luar berbeza dengan pasaran wang yang melibatkan mata wang tempatan sahaja. ${ }^{4}$ Pertukaran asing atau foreign exchange juga dikenali dengan nama singkatan forex atau FX.

Kebiasaanya bank konvensional menawarkan tiga urus niaga pertukaran asing yang utama iaitu FX Spot, FX Forward dan FX Swap bagi memenuhi keperluan pelanggan mereka dan pengurusan mata wang di institusi perbankan masing-masing. Kajian ini akan menilai urus niaga pertukaran asing ini menurut perspektif Syariah. Metodologi kajian yang digunakan ialah penyelidikan perpustakaan dengan meneliti bahan-bahan bertulis tentang konsep al-sarfiatu pertukaran wang dalam Islam,pertukaran asing konvensional dan pandangan ulama tentang pertukaran asing. Seterusnya bahan-bahan kajian ini dinilai dengan menggunakan metode induktif, deduktif dan perbandingan sehingga melahirkan suatu input yang konkrit dan bersesuaian.

\section{PASARAN PERTUKARAN ASING}

Pertukaran asing adalah pasaran terbesar di dunia. Menurut laporan yang dikeluarkan Bank of International Settlements (BIS), ${ }^{5}$ jumlah dagangan harian pertukaran asing pada April 2016 ialah USD5.1 trilion berbanding USD5.4 trilion pada April 2013. Namun begitu, jumlah jumlah dagangan harian pada

3 Bank Negara Malaysia, Bank Negara Malaysia dan Sistem Kewangan di Malaysia: Perubahan Sedekad (Kuala Lumpur: Bank Negara Malaysia, 1999), 302.

4 Mohidin Yahya, Tukaran Asing dan Pasaran Wang, Teori dan Amalan (Kuala Lumpur: Dewan Bahasa dan Pustaka, 1994), 83.

5 Bank of International Settlements terletak di Basel, Switzerland dan mempunyai dua ibu pejabat di Hong Kong dan Mexico. BIS ialah organisasi antarabangsa bagi 60 buah bank negara daripada seluruh dunia. 
Amalan Pertukaran Asing Konvensional:

Analisa Berdasarkan Perspektif Syariah

April 2013 lebih tinggi berbanding hanya USD3.3 trilion pada April 2007. Jumlah dagangan pertukaran asing berkembang dengan amat pesat kerana jumlah dagangan harian pertukaran asing pada tahun 1987 hanya bernilai USD21 bilion. ${ }^{6}$

Pasaran pertukaran asing beroperasi selama 24 jam sehari kerana perbezaan waktu antara bank dengan bank yang lain di kawasan geografi yang berbeza. Sebagai contoh, apabila bank di New York baru mula beroperasi, bank-bank di London sudah beroperasi selama lima jam atau enam jam. Ketika bank di Tokyo ditutup pada jam 5.00 petang, bank di Los Angeles pula baru memulakan operasinya. ${ }^{7}$ Ini bermakna pasaran pertukaran sentiasa beroperasi dan aktif kerana apabila benua tertentu di dunia mulai menutup operasi pertukaran asing terdapat benua lain baharu memulakan operasinya.

Hampir 60\% urus niaga pertukaran asing tertumpu di London, New York dan Tokyo. Manakala 20\% urus niaga pertukaran asing di Zurich, Singapura dan Hong Kong. ${ }^{8}$ Selepas kedua pihak melakukan pertukaran asing, maka mereka perlu uruskan penyelesaian (settlement) kedua mata wang tersebut. ${ }^{9}$ Proses penyelesaian ini dilakukan pada hari bekerja sahaja. Faktor perbezaan zon masa menyebabkan penyelesaian mata wang berlaku terlebih dahulu di bahagian Timur, kemudian di Eropah dan seterusnya di Amerika Syarikat. ${ }^{10}$

\section{URUS NIAGA PERTUKARAN ASING KONVENSIONAL}

Urus niaga FX Spot, FX Forward dan FX Swap mempunyai mekanisme yang berbeza di antara satu sama lain. Penjelasan lanjut bagi ketiga-tiga jenis urus niaga pertukaran asing adalah seperti berikut:

${ }_{6} \quad$ Bank for International Settlements, Trennial Central Bank of Foreign Exchange and Derivatives Market Activity in 2001 (Basel: Bank for International Settlements, 2002), 13; Richard M. Levich, International Financial Markets, Price and Policies (Amerika Syarikat: McGraw-Hill, 1998), 69; J. Orlin Grabbe, International Financial Markets, ed. ke-3 (New Jersey: Prentice-Hall. Inc., 1996), 86; Bank for International Settlements, Triennial Central Bank Survey Foreign Exchange Turnover In April 2016 (Switzerland: Bank for International Settlements, 2016), 3.

7 Mohidin, Tukaran Asing, 81-82; Othman Yong, Pasaran dan Institusi Kewangan di Malaysia Teori dan Amalan (Kuala Lumpur: Dewan Bahasa dan Pustaka, 1993), 215; Grabbe, International Financial Markets, 87.

8 Grabbe, International Financial Markets, 97.

9 Julian Walsmsley, The Foreign Exchange and Money Markets Guide, ed. ke-2 (Kanada: John Wiley \& Sons, Inc., 2000), 161-162.

10 Julian Walsmsley, The Foreign Exchange and Money Markets Guide, 161-162. 


\section{FX Spot}

Urus niaga FX Spot melibatkan dua pihak yang melakukan pertukaran mata wang yang berbeza berdasarkan kadar pertukaran yang telah dipersetujui untuk diserahkan selepas dua hari ${ }^{11}$ (bermula selepas hari urus niaga) atau $\mathrm{T}+2$. Huruf T merujuk kepada satu hari urus niaga dan nombor 2 merujuk kepada dua hari bekerja. ${ }^{12}$ Pada tahun 2016, jumlah dagangan harian dunia bagi FX Spot ialah USD1,654 bilion atau 33\% daripada jumlah urus niaga pasaran pertukaran asing. Urus niaga ini merupakan yang kedua terbesar selepas FX Swap. ${ }^{13}$

Istilah spot atau semerta tidak bermakna pertukaran wang mata wang berlaku pada hari pertukaran yang sama. Tempoh selama 2 hari bekerja telah ditetapkan sebelum kemasukan teknologi canggih dalam pertukaran asing. Maklumat kedua pihak yang berurus niaga perlu diproses selama dua hari untuk memeriksa data transaksi. Sekiranya berlaku kesilapan semasa penyerahan mata wang, maka denda akan dikenakan kepada pihak berkenaan. Justeru itu, tempoh ikekalkan untuk urus niaga FX Spot. ${ }^{14}$

Mata wang yang ditukarkan akan dimasukkan ke dalam akaun bank pihak yang terlibat pada hari penyelesaian iaitu pada $\mathrm{T}+2$. Sekiranya urus niaga melibatkan hari cuti umum seperti hari Sabtu, Ahad atau Tahun Baru, maka penyelesaian akan dilakukan pada hari bekerja berikutnya. Dengan itu, tempoh penyelesaian mata wang akan berlaku pada hari keempat.

\section{FX Forward}

Urus niaga FX Forward ialah dua pihak menukarkan mata wang asing tertentu di antara satu sama lain berdasarkan kadar pertukaran yang dipersetujui untuk diserahkan selepas daripada dua hari atau melebihi tempoh penyelesaian bagi FX Spot. ${ }^{15}$ Hari penyelesaian dalam urus niaga hadapan biasanya dilakukan pada sebulan, 2 bulan, 3 bulan, 6 bulan atau 12 bulan ke hadapan. Dengan

11 Dua hari bermaksud dua hari bekerja dan ia bermula selepas hari urus niaga atau lebih sinonim dengan $\mathrm{T}+2$. Kebiasaan dunia pertukaran asing hanya menyebut dengan ringkas 'dua hari' sahaja.

12 Cornelius Luca, Trading in the Global Currency Markets (New York: Prentice Hall, 2000), 165.

13 Bank for International Settlements, Triennial Central Bank Survey, 9.

14 Cornelius Luca, Trading in the Global Currency Markets, 165-176.

15 Cornelius Luca, Trading in the Global Currency Markets, 179. 
kata lain, setiap penyelesaian yang melebihi dua hari bekerja dikira sebagai FX Forward. ${ }^{16}$

Pada tahun 2016, jumlah dagangan harian dunia bagi FX Forward bernilai USD 700 bilion atau 14\% daripada jumlah keseluruhan pasaran pertukaran asing. Urus niaga ini merupakan yang ketiga terbesar selepas FX Spot dan FX Swap. ${ }^{17}$ Terdapat juga urus niaga yang melibatkan tempoh kematangan yang tidak nomal seperti 37 dan 81 hari namun ia melibatkan kos urus niaga yang agak mahal kerana ia dianggap sebagai urus niaga bukan normal dan melibatkan pengiraan kadar faedah yang lebih tinggi berbanding tempoh penyelesaian normal bagi FX Forward.

\section{FX Swap}

Urus niaga swap ialah pertukaran asing secara spot dengan perjanjian untuk menukar kembali wang asing tersebut pada masa akan datang. ${ }^{18}$ FX Swap adalah urus niaga pertukaran wang terbesar pada April 2016 dengan jumlah dagangan harian bernilai USD2,238 bilion dan atau 47\% daripada pasaran pertukaran asing. ${ }^{19}$

FX Swap kerap digunakan oleh institusi kewangan untuk melindungi pendedahan risiko dalam pasaran hadapan kerana wang yang digunakan tidak terdedah kepada risiko turun naik mata wang. Dana jangka pendek mudah diperolehi melalui urus FX Swap kerana ia melibatkan urus niaga yang ringkas. Selain itu, bank asing tidak perlu risau akan kehilangan wang yang dipinjamkan dan risiko wang dilindungi. Bagi negara yang mempunyai kawalan kewangan yang ketat terhadap aliran keluar modal, urus niaga FX Swap adalah cara untuk mengelak daripada peruntukan perundangan kerana wang yang mengalir keluar akan masuk kembali ke dalam negara. ${ }^{20}$

\footnotetext{
16 Cornelius, Trading in the Global Currency Markets, 174-176.

17 Bank for International Settlements, Triennial Central Bank Survey, 9.

18 M. Levich, International Financial Markets, 92.

19 Bank for International Settlements, Triennial Central Bank Survey, 9.

20 Mohidin Yahya, Tukaran Asing dan Pasaran Wang, Teori dan Amalan, 149-150.
} 


\section{KONSEP PERTUKARAN WANG MENURUT SYARIAH}

Syariah menetapkan peraturan khusus bagi pertukaran wang dengan berpandukan konsep al-ṣarf. Pengertian al-ṣarf menurut majoriti ulama daripada mazhab Shāfi' $\overline{1}$, Hanafī dan Hanbalī ialah jual beli mata wang dengan mata wang sama ada sama jenis atau berbeza jenis. ${ }^{21}$ Contoh jual beli sama jenis seperti pertukaran emas dengan emas dan pertukaran perak dengan perak. Manakala jual beli berbeza jenis seperti pertukaran emas dengan perak.

al-Sarf termasuk dalam kategori jual beli dan tertakluk kepada rukun jual beli yang ditetapkan. Akad al-șarf yang tidak memenuhi rukun adalah fāsid atau batal di sisi syarak. Rukun jual beli terdiri daripada tiga rukun iaitu șighah (lafaz semasa akad), 'āqidān (penjual dan pembeli) dan ma 'qūd'alayh (mata wang yang ditukarkan). ${ }^{22}$

Selain itu, al-șarf mempunyai syarat-syarat lain yang perlu dipatuhi supaya urus niaga yang dilakukan tidak mengandungi unsur riba yang diharamkan. ${ }^{23}$ Syarat-syarat tersebut ialah pertukaran mata wang sama jenis memerlukan persamaan (tamāthul) kuantiti kerana lebihan kuantiti ( $f a d l$ ) yang wujud dalam urus niaga itu ialah riba al-fadl yang diharamkan syarak. ${ }^{24}$ Setiap pertukaran mata wang sama jenis atau berbeza jenis perlu dilakukan qabd sebelum berpisah daripada majlis akad. ${ }^{25}$ Pertukaran mata wang juga tidak boleh dilakukan secara bertangguh kerana kerana ia menyebabkan wujud unsur riba. ${ }^{26}$ Pertukaran mata wang itu juga tidak boleh mengandungi khiyār syart sebagaimana pandangan mazhab Hanafī. Kewujudan khiyār syart

${ }^{21}$ Muhammad Amīn Ibn 'Ābidīn, Radd al-Muhtār 'alā al-Durr al-Mukhtār, vol. 5 (Beirūt: Dār al-Kutub al-'Ilmiyyah, 1992), 257; 'Alā’ al-Dīn Abī Bakr Ibn Mas'ūd al-Kāsānī, Badā' $i$ ' al-Ṣanā' $i$ ' 'alā Tartīb al-Syarā'i', vol. 5 (Beirūt: Dār al-Kutub al-'Ilmiyyah, 1996), 215; Manșur Ibn Yunūs Ibn Idrīs al-Buhūtī, Kasyf al-Qinā' 'an Matn al-Iqnā', vol. 3 (Beirūt: Dār al-Fikr, 1982), 266; Muḥammad Ibn alKhātib al-Syarbīn̄̄, Mughnī al-Muhtāj ilā Ma 'rifah Ma' ānī Alfāza al-Minhāj, vol. 2 (Beirūt: Dār al-Kutub al-'Ilmiyyah, 1994), 369.

22 Manșūr bin Yūnus bin al-Buhūțī, Kasyf al-Qinā' 'an Matn al-Iqnā', vol. 3 (Beirūt: Dār al-Kutub al-'Ilmiyyah, t.t.), 146; al-Syarbīnī, Mughnī al-Muhtāj, vol. 2, 323.

23 'Abbās Aḥmad al-Bāz, Ahkam Șarf al-Nuqūd wa al- 'Umūlāt fì al-Fiqh al-Islāmī wa Tațbìqātuh al-Mu 'āṣirah ('Amman: Dār al-Nafā'is, 1999), 41.

24 Ibn 'Ābidīn, Radd al-Muhtār, vol. 5, 257; al-Buhūțī, Kasysyāf al-Qinā', vol. 3, 254; 'al-Syarbīn̄̄, Mughnī al-Muhtāj, vol. 2, 369.

25 al-Kāsān̄i, Badā'’ ' al-Sanā' 'i', vol. 5, 215; al-Buhūṭî, Kasysyāf al-Qinā', vol. 3, 266; Ibn 'Ābidīn,Radd al-Muhtār, vol. 5, 258.

26 Ibn 'Ābidīn, Radd al-Muhtār, vol. 5, 259. 
menyebabkan pertukaran menjadi fāsid kerana qabḍ adalah syarat sah bagi al-șarf. ${ }^{27}$

Wang kertas yang digunakan dalam urusan harian pada waktu kini tertakluk kepada hukum emas dan perak. Akademi Fiqh Islam Antarabangsa di bawah naungan Pertubuhan Persidangan Islam Sedunia (OIC) pada tahun 1986 dalam persidangannya ke-3 telah mengeluarkan resolusi no. 21 (3/9) tentang Ahkām al-Nuqūd al-Waraqiyyah wa Taghayyur Qìmah al-'Umlah (Hukum Wang Kertas dan Perubahan Nilai Mata wang). Resolusi ini menyatakan wang kertas ialah mata wang kerana ia adalah thamāniyyah (mata wang) yang sempurna. Wang kertas tertakluk kepada semua hukum bagi emas dan perak seperti hukum riba, zakat, salām dan sebagainya. ${ }^{28}$ Berdasarkan resolusi ini, urus niaga pertukaran asing yang berlaku pada hari ini perlu mematuhi al-șarf. Sekiranya urus niaga yang dilakukan mengandungi larangan syarak, maka urus niaga tersebut adalah haram.

Ulama terdahulu hanya membincangkan konsep al-șarf dalam kitab-kitab fiqh dan tidak membincangkan urus niaga pertukaran asing yang terdapat dalam dunia moden sekarang. Urus niaga pertukaran asing hanya mula dibincangkan secara khusus oleh ulama kontemporari yang meliputi urus niaga FX Spot, FX Forward dan FX Swap berdasarkan perspektif Syariah.

\section{ANALISA FX SPOT BERDASARKAN PERSPEKTIF SYARIAH}

Isu utama dalam menentukan hukum FX Spot ialah qabd tidak dilakukan dengan segera dalam majlis pertukaran asing. Qabd terhadap kedua mata wang hanya dilakukan selepas pada dua hari bekerja atau $\mathrm{T}+2$. Kelewatan qabd ini menjadi menjadi perbincangan dalam kalangan ulama kontemporari dan mereka terbahagi dua pendapat iaitu pendapat yang mengharamkan FX Spot dan pendapat yang mengharuskan FX Spot.

\section{Pendapat Pertama: FX Spot adalah Haram}

Pendapat pertama mengatakan FX Spot adalah haram kerana menyalahi syarak. Pandangan ini dipegang oleh segelintir ulama kontemporari seperti

al-Kāsānī, Badā' 'i ‘ al-Șanā'i', vol. 5, 219.

28 Majma' al-Fiqh al-Islāmī al-Dawlī, 'Qarār,' laman sesawang Majma ‘ al-Fiqh alIslāmī al-Dawlì, http://www.iifa-aifi.org/1679.html, dicapai 11 Disember 2015. 
Sheikh Sālih al-Marzūqī, ${ }^{29}$ Muhammad Akram Khan, ${ }^{30}$ Sheikh Fathī Salīm Ghazā ${ }^{31}$ dan sebagainya. Kelewatan serahan mata wang dalam FX Spot yang mengambil masa selama dua hari bekerja ini menyalahi hadis Nabi SAW yang jelas menunjukkan qabd perlu dilakukan dengan segera semasa majlis pertukaran. Nabi SAW bersabda seperti berikut:

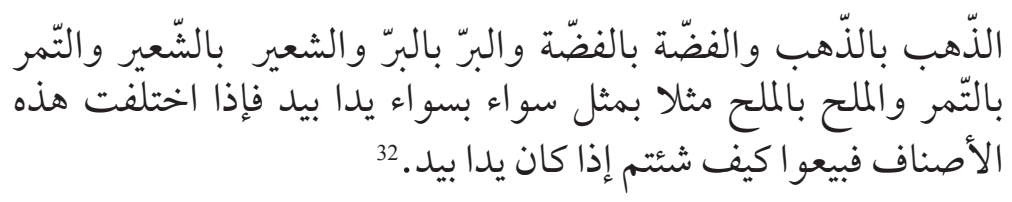

"(Tukarlah) emas dengan emas, perak dengan perak, gandum dengan gandum, barli dengan barli, kurma dengan kurma, garam dengan garam dengan sama kuantiti dan tangan dengan tangan (qabd). Apabila berlainan jenis, maka tukarlah mengikut yang kamu suka apabila ia dilakukan dengan tangan dengan tangan (qabd)."

Nabi SAW juga menyebut perkara yang sama kepada Ibn 'Umar RA seperti berikut:

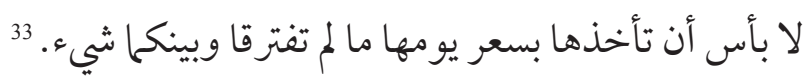

29 Majma' al-Fiqh al-Islāmī, 'al-Muḍārabah fī al-'Umlah, al'Arḍ-al-Ta'qīb wa alMunāqasyah' dalam 'al-Muḍārabah fī al-'Umlat wa al-Wasā'il al-Masyrū'ah li Tajtnanib Aḍrāhā al-Iqtișādīyah,' Majallah Majma ' al-Fiqh al-Islāmī, vol. 1/11 (1998): 569.

30 Muhammad Akram Khan, 'Commodity Exchange and Stock Exchange in An Islamic Economy,' The American Journal of Islamic Social Science, vol.5/1 (1998): 101-102.

31 Fatḥ̄ Salīm Ziyād Ghazāl, Hukm al-Syar ' fì al-Burșah ('Amman: Dār al-Waddāḥ, 2008), 37.

32 Hadis riwayat Muslim, Kitāb al-Musāqah, Bāb al-Șarf wa Bay al-Dhahab bi al-Wariq Naqdan, no. hadis 1587. Lihat Muslim bin al-Hajjāj al-Nisābūrī, Șaḥ̄h Muslim, vol. 3 (Beirūt: Dār Iḥyā' al-Turāth al-'Arabī, t.t.), 1211.

33 Hadis riwayat Abū Dāwud, Sunan Abī Dāwud, Kitāb al-Buyū', Bāb fĩ Iqtidā’ alDhahab min al-Wariq, hadis no. 3354. Lihat Abū Dāwud Sulaymān bin al-Asy'ath, Sunan Abī Dāwud, vol. 3 (Beirūt: al-Maktabah al-'Asriyah, t.t), 250. al-Mundhīrī mengatakan hadis ini turut dikeluarkan oleh al-Tirmīzī, al-Nasā'̄i dan Ibn Mājah. Hadis ini berstatus marfü ' melalui Samāk bin Harb. Lihat Muḥammad Asyraf bin Amīr al-'Az̄ìm Ābādi, 'Awn al-Ma 'būd Syarḥ Sunan Abī Dāwud (Beirūt: Dār alKutub al-'Ilmiyyah, 1995), vol. 9, 146. 
Amalan Pertukaran Asing Konvensional:

Analisa Berdasarkan Perspektif Syariah

"Tidak ada masalah jika kamu menerimanya dengan harga pada hari tersebut dan kamu berdua tidak berpisah dan di antara kamu berdua tiada sesuatu (baki wang yang belum dibayar)."

'Umar bin al-Khațāa juga melarang pertukaran dirham (perak) dengan emas tanpa dilakukan qabọ di dalam majlis akad seperti berikut:

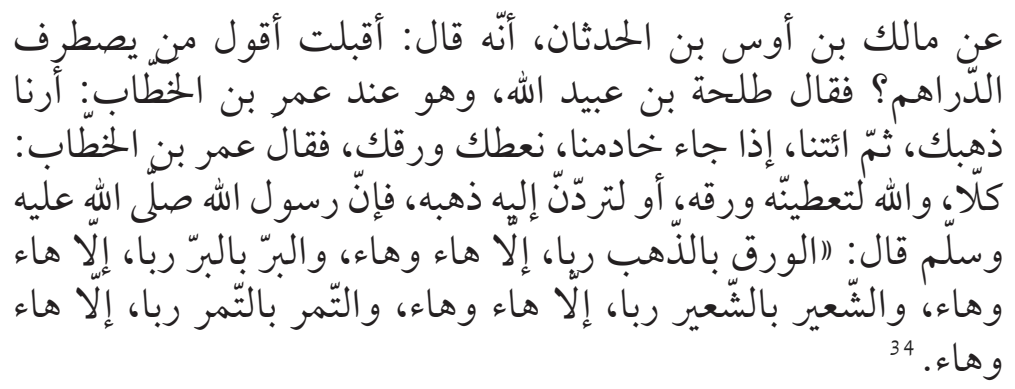

"Daripada Mālik Ibn Aws Ibn Hadathān, bahawa dia berkata: Aku berpaling kepada orang ramai dan aku berkata: Siapa yang mahu menukar dirham? Kemudian Talhah bin 'Ubayd Allāh berkata, dia sedang berada di sisi 'Umar bin al-Khaț̣āb: Tunjukkan emas kamu, kemudian bawakannya kepada kami, apabila datang khadam kami, kami akan berikan kepada kamu wang perak (wariq). Maka 'Umar bin al-Khațāb berkata: Janganlah kamu berbuat demikian. Demi Allah! Kamu hendaklah berikan kepadanya wang perak atau kamu pulangkan kepadanya emasnya. Sesungguhnya Rasulullah SAW pernah bersabda: Jual beli perak dengan emas adalah riba kecuali (salah seorang berkata) "ambil ini" dan (seorang lagi berkata) "ambil ini". (Pertukaran) barli dengan barli adalah riba kecuali (salah seorang berkata) "ambil ini" dan (seorang lagi berkata) "ambil ini". (Pertukaran) gandum dengan gandum adalah riba kecuali (salah seorang berkata) "ambil ini" dan (seorang lagi berkata) "ambil ini". (Pertukaran) kurma dengan kurma adalah riba kecuali (salah seorang berkata) "ambil ini" dan (seorang lagi berkata) "ambil ini”.

Semua dalil di atas menunjukkan qabd perlu dilakukan semasa pertukaran yang melibatkan emas dengan emas atau emas dengan perak. Qabd perlu dilakukan sebelum kedua pihak yang terlibat berpisah daripada majlis

34 Riwayat Muslim, Kitāb al-Buyū', Bāb al-Șarf wa Bay' al-Dhahab bi al-Wariq Naqdan, no. hadis 1584. Lihat Muslim, Șaḥ̄h Muslim, vol. 3, 1209. 
pertukaran. Sekiranya pertukaran dilakukan tanpa qabd, maka urus niaga yang dilakukan terlibat dengan riba. Dengan itu, sebarang pertukaran asing perlu dilakukan secara qabd bagi kedua-dua mata wang yang ditukar dalam majlis akad.

Golongan ini lebih menumpukan kepada persoalan qabd yang perlu dilakukan dengan segera dalam pertukaran asing. Kelewatan penyerahan mata wang dalam FX Spot tidak memungkinkan berlaku qabd sebagaimana yang disebut dalam hadis Nabi SAW. Namun konsep qabd dalam pandangan Syariah ditetapkan oleh uruf. Cara qab dengan teliti dalam menentukan hukum.

Golongan ini juga membantah hujah kaedah fiqh "al-masyaqqah tajlib al-taysìr" (kesulitan membuka kepada kemudahan) yang digunakan oleh golongan yang mengharuskan FX Spot. Hal ini disebabkan kaedah fiqh ini bertentangan dengan dalil yang jelas dan sahih yang disebutkan dalam hadishadis Nabi SAW. ${ }^{35}$ Hadis-hadis Nabi SAW perlu diutamakan berbanding dengan kaedah fiqh yang mengharuskan FX Spot.

Kelewatan penyerahan mata wang dalam FX Spot menyebabkan wujud unsur riba atau faedah urus niaga yang dilakukan. Tempoh penyerahan mata wang akan mempengaruhi kadar faedah dalam pengiraan kadar pertukaran. ${ }^{36}$ Dengan itu, elemen riba ini menyebabkan urus niaga FX Spot adalah haram.

Sebenarnya tidak timbul persoalan riba dalam pertukaran FX Spot kerana kadar sesuatu mata wang dibenarkan berbeza di antara satu sama lain dalam pertukaran. Kadar faedah yang digunakan adalah untuk menentu kadar pertukaran dengan menggunakan formula pengiraan tertentu. Setiap pertukaran asing hanya menggunakan kadar pertukaran yang dipersetujui oleh kedua pihak.

Kajian mendapati tiada fatwa daripada majlis fatwa, persidangan fiqh atau jawatankuasa Syariah di institusi perbankan Islam yang bersetuju dengan pendapat golongan ini yang mengatakan FX Spot adalah haram. Ini mungkin disebabkan hujah yang digunakan oleh golongan ini tidak beberapa kuat berbanding dengan pendapat yang mengharuskan FX Spot.

35 Majma' al-Fiqh al-Islāmī, 'al-Muḍārabah fĩ al-‘Umlah,' vol. 1, 569.

36 Muhammad Akram, 'Comodity Exchange,' 101-102 'Āṣim Aḥmad 'Āṭ̂yah Badw̄ī, 'Aḥkam al-Ṣarf al-Ilikturūn̄̄ fī al-Fiqh al-Islāmī', (Tesis sarjana, Kuliah Syariah dan Undang-Undang, Universiti Islam Gaza, Palestin, 2010), 82. 
Amalan Pertukaran Asing Konvensional:

Analisa Berdasarkan Perspektif Syariah

\section{Pandangan Kedua: FX Spot Adalah Harus}

Pendapat kedua mengatakan FX Spot adalah harus dan mematuhi syarak. Pendapat ini dipegang oleh majoriti ulama kontemporari seperti Syeikh Yūsuf al-Qaraḍawī, ${ }^{37}$ Sheikh Muḥy al-Dīn al-Qurahdaghī, ${ }^{38}$ Dr. Nazīh Kamal Hamad, ${ }^{39}$ Dr. Aḥmad Muḥy al-Dīn Aḥmad, ${ }^{40}$ Sheikh Yūsuf al-Syubaylīin dan sebagainya. Kebanyakan ulama mengharuskan urus niaga FX Spot walaupun qabd hanya berlaku pada dua hari bekerja selepas hari urus niaga kerana konsep qabḍ ditafsirkan berdasarkan kepada keadaan barangan dan 'urf.

Golongan ini bersetuju bahawa hukum asal bagi jual beli mata wang ialah qabọ bagi mata wang perlu dilakukan dengan segera seperti yang dinyatakan dalam hadis Nabi SAW. Dengan itu, tidak sah penyerahan mata wang secara bertangguh dalam pertukaran wang. Perkara ini disebut dalam hadis riwayat Ibn 'Umar RA:

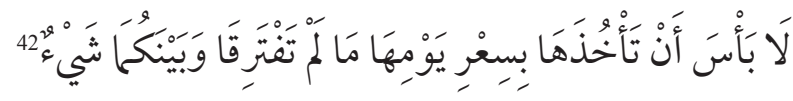

"Tiada masalah jika kamu menerimanya dengan harga pada hari tersebut dan kamu berdua tidak berpisah dan di antara kamu berdua tiada sesuatu (baki wang yang belum dibayar)."

Pada masa yang sama golongan ini berpandangan tafsiran qabọ perlu bergantung kepada 'urf dan keadaan barangan yang terlibat dalam urus niaga tersebut. 'Urf dalam pertukaran asing perlu diambil kira dalam memahami mekasnime qabd yang dilakukan dengan segera. Pemahaman qabd ini adalah aspek penting dalam menentukan hukum FX Spot. Tafsiran qabọ ini juga bergantung kepada pengertian keperluan (d̦arūriyyāt) semasa mengikut kadar atau tempoh yang bersesuaian berdasarkan syarak ${ }^{43}$

\footnotetext{
37 Yūsuf al-Qaraḍāwī, 'Hawl (Fawrīyah al-Qabḍ) fī al-Bay' al-'Umulāt,' laman sesawang al-'Allāmah al-Qaradāwī, http://www.qaradawi.net/new/allfatawa/6655-q-q, dicapai 12 Januari 2016.

38 Majma' al-Fiqh al-Islāmī, 'al-Muḍārabah fĩ al-'Umlah,' 579.

39 Nazīh Kamal Ḥamad, 'al-Qabḍ al-Ḥaqīīì wa al-Ḥukmī: Qawā'id wa Taṭbīqātuh min al-Fiqh al-Islāmī,' Majallah Majma 'al-Fiqh al-Islāmī, vol. 1/6 (1990): 723.

40 Aḥmad Muḥy al-Dīn Ahmad, 'al-Muḍārabah fĩ al-'Umlah wa al-Wasā'il alMasyrū'ah li-Tajtanib Aḍrārahā al-Iqtișādīyah,' Majallah Majma' al-Fiqh alIslāmī, vol. 1/ 11 (1998): 454.

41 Yūsuf bin 'Abd Allāh al-Shubaylī, 'al-Khadamāt al-Mașrafiyyah li-Istithmār Amwāl al-'Umalā' wa Aḥkāmuhā fĩ al-Fiqh al-Islāmī', (Tesis kedoktoran, Jabatan Fiqh Perbandingan, al-Ma'had al-'Ālī li al-Qaḍā', Riyāụ, 2002), 272.

42 Sila rujuk takhrīj hadis pada nota kaki nombor 33.

43 Yūsuf al-Qaraḍ̄̄īi, 'Hawl (Fawrīyyah al-Qabḍ).'
} 
Perkara ini diperkuatkan lagi dengan pandangan ulama silam seperti Imam al-Nawāwī, Ibn Qudāmah, Ibn Taymiyyah, Khātib al-Syarbīnī dan sebagainya yang mengatakan qabd ditentukan oleh 'urf. ${ }^{44}$ Ini disebabkan syarak dan bahasa tidak menjelaskan mekasnime qabd dan ia terpulang kepada tafsiran 'urf manusia. ${ }^{45}$

Dengan itu, penyerahan mata wang pada $\mathrm{T}+2$ adalah tempoh yang diakui dan diiktiraf sebagai tempoh penyelesaian dalam pasaran pertukaran asing antarabangsa. Semua pihak perlu mematuhi sistem penyelesaian yang ditetapkan. Dengan itu, golongan ini berpandangan kelewatan qabd dalam FX Spot tidak menyalahi syarak bahkan ia adalah uruf dalam pasaran pertukaran asing.

Selain itu, isu kelewatan penyerahan mata wang dalam FX Spot juga tidak dapat dielakkan kerana kedua pihak tidak dapat melakukan qabd secara fizikal ( haqīq $)$ atau hukmī. Ini disebabkan pelbagai faktor luaran yang berada di luar kawalan pihak yang melakukan kontrak pertukaran asing seperti jarak yang berjauhan yang menyukarkan penyerahan mata wang secara fizikal dengan segera. Selain itu, transaksi FX Spot yang dilakukan perlu mematuhi peraturan pertukaran asing antarabangsa. Syariah membuka kemudahan bagi kesulitan yang ditidak dapat dielakkan dalam pertukaran asing ini berdasarkan kaedah fiqh "al-masyaqqah tajlib al-taysīr" (kesulitan membuka kepada kemudahan).

Urus niaga FX Spot amat penting dan diperlukan terutama dalam perniagaan antarabangsa. Peniaga yang memerlukan mata wang seperti Dolar Amerika dan Pound Australia perlu mendapatkan mata wang tersebut melalui pasaran pertukaran asing dan menggunakan sistem peraturan yang telah wujud sekian lama. Keperluan penting ini bersesesuaian dengan kaedah Syariah "almaṣlaḥah al-rājiḥah wa al-hājah al-khāṣah allatī tanzil manzilah al-darūrah" (mașlahah yang terkuat dan kehendak khas menduduki tahap keperluan penting). Dengan itu, FX Spot perlu diharuskan bagi menyempurnakan mașlahah dan kepentingan masyarakat. Jika urus niaga pertukaran asing ini dilarang, maka sudah pasti akan mengundang kesulitan yang lebih besar. ${ }^{46}$

44 Muhy al-Dīn Yahyā bin Syarf al-Nawāwī, al-Majmū ‘ Syarḥ al-Muhadhdhab, vol. 9 (Damsyik: Dār al-Fikr, t.t.), 27-5276; 'Abd Allāh bin Aḥmad bin Qudāmah alMuqaddasī, al-Mughnī li Ibn Qudāmah, vol. 4 (Qāhirah: Maktabah al-Qāhirah, 1968), 85; Aḥmad bin 'Abd al-Halīm Ibn Taymīyah, Majmū'ah al-Fatāwā (Madinah: Majma' al-Malik Fahd li Țibā'ah al-Muṣhaf al-Syarīf, 1995), vol. 20, 448; al-Syarbīnī, Mughnī al-Muhtāj, vol. 2, 467.

45 Nazīh Ḥamad, 'al-Qabụ al-Haqīīi,' 723.

46 Aḥmad Muḥy al-Dīn, 'al-Muḍārabah fĩ al-'Umlah,' vol. 1, 454. 
Amalan Pertukaran Asing Konvensional:

Analisa Berdasarkan Perspektif Syariah

Sehingga kini hanya terdapat satu sahaja sistem urus niaga FX Spot yang diamalkan di seluruh dunia dan ia amat penting bagi urusan orang ramai. Jika FX Spot diharamkan, maka tiada alternatif yang dapat digunakan oleh institusi perbankan Islam jika mereka memerlukan sejumlah nilai mata wang asing yang besar. ${ }^{47}$ Senario ini menunjukkan keperluan yang tinggi terhadap urus niaga FX Spot bagi memenuhi permintaan pelanggan dan pihak institusi perbankan Islam.

Pendapat yang mengharuskan FX Spot ini dipersetujui oleh kebanyakan majlis fatwa antarabangsa. Akademi Fiqh Islami OIC dalam persidangannya kali ke-6 di Jeddah, Saudi Arabia pada 14-20 Mac 1990 mengeluarkan resolusi no. 6/4/55 yang menjelaskan qabd mempunyai pelbagai cara dan ditentukan berdasarkan keadaan barangan dan 'urf masyarakat. Qabḍ dalam pertukaran asing adalah diharuskan berdasarkan 'urf pasaran. Selain itu, pemindahan mata wang melalui akaun bagi kedua pihak yang melakukan urus niaga pertukaran asing adalah dikira sebagai qabd hukmī dan menyamai hukum qabọ secara fizikal.

Resolusi ini juga mengharuskan kelewatan qabḍ mata wang yang berlaku dalam urus niaga FX Spot dan menganggap ia adalah 'urf perniagaan yang tidak dapat dielakkan. Namun begitu, pihak yang menerima mata wang tidak dibenarkan melakukan jual beli ke atas mata wang tersebut dalam tempoh tersebut sehingga dia mampu melakukan penyerahan mata wang secara fizikal kepada pihak ketiga. ${ }^{48}$

Accounting and Auditing Organization for Islamic Financial Institutions (AAOIFI) melalui Paramater Syariah no. 1 tentang al-Mutājarah al- 'Umulāt (Perdagangan Mata Wang) turut mengharuskan FX Spot yang dilakukan dalam pasaran pertukaran asing. Parameter yang dikeluarkan oleh AAOIFI ini mengambil sepenuhnya resolusi no. 6/4/55 yang dikeluarkan oleh Akademi Fiqh Islami OIC. ${ }^{49}$

Dewan Syariah Nasional bagi Majelis Ulama Indonesia turut membenarkan FX Spot melalui fatwa no. 28/DSN-MUI/111/2002 tentang Jual Beli Mata uang (Al-Sharaf). Fatwa ini menyebut bahawa urus niaga ini diharuskan kerana

47 Majma' al-Fiqh al-Islāmī, 'al-Muḍārabah fī al-‘Umlah,' vol. 1, 591.

48 Majma' al-Fiqh al-Islamī, 'al-Qabḍ: Șūrah wa bi Khāṣah al-Mustajiddah minhā wa Aḥkāmuhā,' laman sesawang Majma' al-Fiqh al-Islamī, http://www.iifa-aifi. org/2035.html, dicapai 16 September 2016.

49 Hay’ah al-Muhāsabah wa al-Murāja'ah li al-Mu'assah al-Mālīyah al-Islāmiyyah, al-Ma 'āyir al-Syar 'iyyah (Manama: Hay'ah al-Muhāsabah wa al-Murāja'ah li alMu'assah al-Māliyyah al-Islāmiyyah, 2010), 4-5. 
tempoh berkenaan dianggap sebagai tunai dan tempoh ini sukar dihindari dalam FX Spot. Selain itu, qabọ dalam tempoh ini juga adalah amalan dalam pertukaran asing antarabangsa. ${ }^{50}$

Majlis Penasihat Syariah di Bank Negara Malaysia (BNM) pada mesyuarat ke-38 bertarikh 28 Ogos 2003 juga memutuskan bahawa penyerahan dan penyelesaian urus niaga mata wang asing secara semerta yang dibuat pada $\mathrm{T}+2$ adalah dibenarkan. Penyelesaian dan penyerahan secara $\mathrm{T}+2$ diterima dalam urus niaga secara lani kerana tempoh masa sebegini adalah perlu bagi pihak-pihak yang berurus niaga membuat pengesahan. Sistem penyelesaian dan pembayaran sedemikian telah diterima sebagai uruf perniagaan. ${ }^{51}$

Pandangan golongan ini juga dipersetujui oleh jawatankuasa Syariah institusi perbankan Islam seperti Lembaga Syariah Bank Al Rajhi di Saudi Arabia melalui resolusi no. 195 tentang al-Mușārafah al-Fawriyyah fì al'Umulāt wa al-Dhahab wa al-Fiḍdah (Pertukaran Segera bagi Mata Wang, Emas dan Perak) dan Lembaga Syariah Bank Al Bilād di Saudi Arabia melalui Parameter no. 447.52

Lembaga Syariah Bank Al Rajhi menetapkan perkara asas dalam jual beli mata wang ialah taqābuḍ dalam majlis akad. Maka dibenarkan taqāa $b u d$

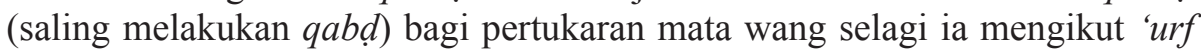
dalam pasaran pertukaran FX Spot iaitu memerlukan $\mathrm{T}+2$ untuk serahan mata wang ke dalam akaun masing-masing. Keputusan mengharuskan FX Spot berdasarkan justifikasi berikut:

a) Kesukaran melakukan rekod perakaunan bagi pertukaran asing semasa majlis akad terutama apabila melibatkan negara yang berbeza. Kaedah fiqh menyebut inna al-amr idhā dāqa ittasa 'a (sesungguhnya sesuatu perkara apabila menjadi sempit, maka ia akan menjadi luas). Dengan itu, kelewatan penyerahan mata wang selama $\mathrm{T}+2$ dianggap sebagai imtidād li majlis (tempoh majlis kontrak yang dipanjangkan) dan sebagai akad khas.

b) Pertukaran asing adalah kontrak yang harus dan merupakan hājah 'ammah (kehendak umum). Amalan pasaran pertukaran asing pula memerlukan

50 Dewan Syariah Nasional, 'Fatwa Dewan Syari'ah Nasional Nomor 28/DSNMUI/III/2002 Jual Beli Mata Uang (al-Sharf),' laman sesawang Dewan Syariah Nasional-Majelis Ulama Indonesia, http://www.dsnmui.or.id/index.php?mact=Ne ws, cntnt01,detail,0\&cntnt01 articleid=29\&cntnt01 origid $=59 \& \operatorname{cntnt} 01$ detailtempl ate $=$ Fatwa\&cntnt01 returnid=15\&cntnt01 returnid=15, dicapai 1 Oktober 2016.

51 Bank Negara Malaysia Berhad, Resolusi Syariah dalam Kewangan Islam Edisi Kedua (Kuala Lumpur: Bank Negara Malaysia, 2010), 137-138.

52 Amānah al-Hay’ah al-Syar'iyyah, al-Ḍawābị̣ al-Mustakhlaṣah min Qarārāt alHay’ah al-Syar‘iyyah li Bank al-Bilād (Riyāḍ: Dār al-Mayman, 2013), 134. 
tempoh $\mathrm{T}+2$ untuk serahan mata wang. Hājah 'ammah ini menjadikan kelewatan selama dua hari ini sebagai darürah (keperluan) dan häjah khāṣah (kehendak khas). Oleh itu, perkara ini dimaafkan berdasarkan kaedah tadi walaupun ia menyalahi kaedah asal bahawa taqābud perlu dilakukan dalam majlis akad.

c) Tempoh qabd kedua mata wang yang terlibat dalam FX Spot telah menjadi uruf dalam pasaran pertukaran asing. Oleh yang demikian, qabd ini dianggap sebagai qabd fawrī (segera). ${ }^{53}$

\section{Pandangan Terpilih}

Berdasarkan hujah-hujah yang dikemukakan oleh kedua pandangan di atas, penulis memilih pandangan majoriti ulama yang mengatakan FX Spot adalah harus kerana qabd pada sesuatu perkara bergantung kepada keadaan perkara itu sendiri dan uruf pasaran. Serahan mata wang pada $\mathrm{T}+2$ dianggap uruf dalam urus niaga FX Spot. Walaupun berlaku kelewatan serahan mata wang bagi kedua pihak namun serahan pada $\mathrm{T}+2$ dianggap sebagai qab dalam pasaran pertukaran asing.

Kelewatan penyerahan mata wang dalam urus niaga FX Spot tidak dapat dielakkan oleh kedua pihak apabila menggunakan sistem pertukaran asing. Sekiranya mekanisme qabd pada $\mathrm{T}+2$ dalam transaksi FX Spot tidak diterima, maka ia akan memberikan kemudaratan yang lagi besar kepada mereka yang terlibat dalam pasaran antarabangsa dan pihak yang memerlukan mata wang asing untuk memenuhi keperluan masing-masing. Walau bagaimanapun, tempoh qabd dalam FX Spot tidak boleh dikaitkan untuk urus niaga FX Forward kerana urus niaga ini melibatkan tempoh melebihi urus niaga FX Spot.

\section{ANALISA FX FORWARD BERDASARKAN PERSPEKTIF SYARIAH}

Isu utama dalam FX Forwad ialah persoalan qabd bagi kedua mata wang yang terlibat dalam pertukaran. Ulama kontemporari berbeza pandangan tentang FX Forward dan terbahagi kepada dua pandangan iaitu pandangan yang mengharuskan FX Forward dan pandangan yang mengharamkan FX Forward.

33 al-Majmū'ah al-Syar'iyyah, Qarārāt al-Hay’ah al-Syar'iyyah bi Mașraf al-Rājiḥ̄, vol. 1 (Riyāọ: Dār Kunūz Isybīlīyā li Nasyr wa al-Tawzī‘, 2010), 317-319. 


\section{Pandangan Pertama: FX Forward adalah Harus}

Pandangan pertama mengatakan FX Forward adalah harus kerana ia bertepatan dengan Syariah. Pandangan ini adalah terpencil dan dipegang oleh sesetengah pihak yang mengharuskan urus niaga FX Forward. Mereka berpendapat urus niaga FX Forward ialah perjanjian (muwā'adah) dua pihak untuk melakukan pertukaran asing pada masa hadapan berdasarkan kadar pertukaran yang telah dipersetujui. Semasa perjanjian tiada sebarang penyerahan mata wang dilakukan. Hukum perjanjian untuk jual beli mata wang asing adalah diharuskan oleh Syariah. ${ }^{54}$

Inilah hujah utama yang digunakan oleh golongan ini dalam mengharuskan FX Forward. Pada prinsipnya diharuskan melakukan perjanjian untuk melakukan pertukaran mata wang pada masa hadapan. Namun perjanjian yang dilakukan tidak boleh bersifat mengikat kedua pihak kerana ia akan menyebabkan perjanjian menyerupai kontrak pertukaran wang. Sebarang pertukaran wang yang melibatkan serahan bertangguh adalah diharamkan oleh syarak.

Keperluan terhadap urus niaga FX Forward amat tinggi kerana ia digunakan sebagai lindung nilai bagi pengimport dalam perdagangan antarabangsa. Kaedah fiqh yang digunakan dalam hal ini ialah "al-hājah alkhāṣah tanzil manzilah al-darürah" (keperluan khas mempunyai kedudukan yang sama dengan keperluan asas) dan kaedah "umum al-balwa" (kerosakan yang tersebar luas). Pengimport tidak memperoleh keuntungan atau manfaat daripada urus niaga FX Forward. Mereka hanya menggunakan FX Forward untuk melindungi nilai mata wang daripada pergerakan kadar mata wang yang buruk pada masa hadapan. ${ }^{55}$

Konsep lindung nilai dibenarkan oleh Islam namun instrumen yang digunakan perlu dipastikan mematuhi Syariah. Sekiranya instrumen tersebut tidak mematuhi Syariah, maka secara automatik ia tidak diharuskan walaupun objektif asalnya dibenarkan. Begitu juga dengan urus niaga FX Forward yang bertentangan dengan peraturan syarak, maka ia tidak diharuskan walaupun digunakan untuk lindung nilai. ${ }^{56}$

Kajian mendapati tiada fatwa daripada majlis fatwa, persidangan fiqh atau jawatankuasa Syariah di institusi perbankan Islam yang bersetuju dengan pandangan yang mengharuskan FX Forward. Ini kemungkinan disebabkan

\footnotetext{
54 Aḥmad Muḥy al-Dīn, 'al-Muḍārabah fĩ al-'Umlah,' vol. 1, 456.

55 Aḥmad Muḥy al-Dīn, 'al-Muḍārabah fĩ al-‘Umlah,' vol. 1, 456.

56 Hay’ah al-Muhāsabah, al-Ma 'āyir al-Syar 'iyyah, 4.
} 
Amalan Pertukaran Asing Konvensional:

Analisa Berdasarkan Perspektif Syariah

hujah yang digunakan oleh golongan ini tidak mempu mengatasi hujah yang mengharamkan FX Forward.

\section{Pandangan Kedua: FX Forward adalah Haram}

Pandangan kedua mengatakan FX Forward adalah haram. Pandangan in ini dipegang oleh majoriti ulama kontemporari seperti Sheikh 'Alī al-Salūs, ${ }^{57}$ Sheikh 'Abd al-Sattār Abū Ghuddah, ${ }^{58}$ Dr. Ahmmad Muhyy al-Dīn Aḥmad, ${ }^{59}$ Dr. 'Abd al-Bārī al-Misy'al, ${ }^{60}$ Sheikh Yūsuf al-Shubaylīi1 dan sebagainya.

Golongan ini berpendapat pertukaran mata wang dengan mata wang lain secara serahan bertangguh tidak dibenarkan oleh syarak. Ini disebabkan ia tidak memenuhi syarat qabd yang disepakati oleh ulama sebagai syarat sah untuk akad al-șarf. ${ }^{62}$ Hukum ini berdasarkan hadis yang diriwayatkan oleh Sa‘̄̄d al-Khudrī RA bahawa Rasulullah SAW bersabda: ${ }^{63}$

$$
\text { و لا تبيعو ا منها غائبا بناجز }
$$

"Jangan kamu menukar barangan yang ada dengan barangan yang tiada."

Hadis ini melarang jual beli mata wang yang ada dengan mata wang yang tiada semasa majlis pertukaran dilakukan. Jika kedua mata wang yang ingin ditukarkan tiada semasa majlis pertukaran, maka sudah tentu ia juga dilarang. Perkara ini diperkuatkan lagi dengan ijmak ulama bahawa tidak sah pertukaran

57 Majma' al-Fiqh al-Islāmī, 'al-Muḍārabah fī al-‘Umlah,' vol.1, 592.

58 Abū Ghuddah, Buhūth fì al-Mu'àmalāt wa al-Asālīb al-Mașrafìyah al-Islāmīyah, vol. 8 (Jeddah: Majmū'ah Dallah al-Barakah, 2007), 111.

59 Aḥmad Muḥy al-Dīn, 'al-Muḍārabah fĩ al-‘Umlah,' vol. 1, 452-455.

60 'Abd al-Bārī Misy'āl, 'Dawabị̣ Șarf al-'Umulāt wa Badāil al-Taḥawwuṭ alMasyrū'ah fī al-Mu'assasah al-Māliyah al-Islāmiyyah,' (Kertas kerja, Mulataqā al-Khurtūm li al-Muntajāt al-Māliyyah al-Islāmiyyah, Markāz Bayān li Ḥandasah al-Māliyyah al-Islāmiyyah, 6-5 April 2012), 5.

61 Yūsuf al-Syubaylī, 'al-Khadamāt al-Mașrafiyyah,' vol. 3, 272.

62 Abū Sattār Abū Ghuddah, Buhūth fì al-Mu'āmalāt, vol. 8, 111; 'Abd al-Bārī Misy'āl, 'Dawabiụ Șarf al-'Umulāt,' 5; Aḥmad Muḥy al-Dīn, 'al-Muḍārabah fī al-'Umlah,' vol. 11, 452-455.

63 Riwayat al-Bukhārī, Kitāb al-Buyū‘, Bāb Bay‘ al-Fiddah bi al-Fiddah, no. hadis 2177 dan Muslim, Kitāb al-Musāqah, Bāb al-Riba, no. hadis 1584. Lihat Muḥammad bin Ismā'il al-Bukhārī, Șahīh al-Bukhārī, vol. 3, ed. Muḥammad Z̄āhir bin Nāṣir al-Nāṣir (Beirūt: Dār al-Ṭūq al-Najāh, 2001), 74 dan Muslim, Sahịh Muslim, vol. 3, 1208. 
mata wang secara bertangguh. ${ }^{64}$ Rasulullah SAW juga melarang jual beli emas dengan perak secara berhutang sebagaimana hadis berikut:

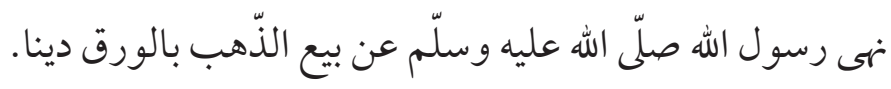

"Rasulullah SAW melarang menukar emas dengan perak secara berhutang (bertangguh)." 65

Ulama kontemporari menerima tempoh qabd selama $\mathrm{T}+2$ dalam urus niaga FX Spot kerana ia adalah uruf pasaran pertukaran asing dan peraturan yang tidak dapat dielakkan oleh semua pihak. Namun penyerahan mata wang dalam urus niaga FX Forward melibatkan tempoh yang melebihi $\mathrm{T}+2$ iaitu sebulan, dua bulan, tiga bulan atau enam bulan ke hadapan. Dengan itu, tempoh kelewatan qabd dalam FX Forward tidak diterima sebagai qabd yang diakui oleh Syariah. Maka kelewatan penyerahan mata wang dalam FX Forward adalah menyalahi hadis-hadis Nabi SAW.

Selain itu, kelewatan penyerahan kedua mata wang dalam urus niaga FX Forward menyebabkan timbul unsur bay ' al-kalī' bi al-kalì' (jual beli hutang dengan hutang) yang diharamkan secara ijmak ulama. ${ }^{66}$ Apabila kedua pihak melakukan kontrak FX Forward namun penyerahan mata wang dilakukan secara bertangguh, maka kedua pihak saling berhutang di antara satu sama lain. Senario ini dikategorikan dalam larangan jual beli hutang dengan hutang.

FX Forward bukan merupakan perjanjian (muwa' 'adah) untuk melakukan pertukaran asing pada masa hadapan kerana apabila kedua pihak bersetuju ke atas kadar pertukaran FX Forward, maka ia telah mengikat kedua pihak. Pihak yang terlibat dalam urus niaga tidak boleh membatalkan urus niaga itu walaupun terdapat pihak tertentu yang terpaksa menanggung kerugian. ${ }^{67}$ Ini menunjukkan kedua pihak melakukan kontrak jual beli mata untuk penyerahan mata wang secara bertangguh dan bukan perjanjian untuk melakukan urus niaga pada masa hadapan. Syarak tidak membenarkan jual beli mata wang yang melibatkan serahan secara bertangguh. Larangan urus niaga FX Forward adalah berdasarkan dalil qaț 'i al-thubüt wa al-dilālah (jelas ketetapan dan petunjuk) dan hujah yang mengharuskan FX Forward tidak dapat menangkis hujah pengharamannya. ${ }^{68}$

\footnotetext{
${ }_{64}$ Aḥmad Muḥy al-Dīn, 'al-Muḍārabah fĩ al-‘Umlah,' vol. 11, 452-455.

65 Hadis riwayat al-Bukhārī, Kitab al-Buyū', Bab Bay‘ al-Wariq bi al-Dhahab Nas̄̄’ah, no. hadis 2180. Lihat al-Bukhārī, Șaḥịh al-Bukhārī, vol. 3, 75.

66 al-Shubaylī, 'al-Khadamāt al-Mașrafiyyah,' vol. 3, 272.

67 Majma' al-Fiqh al-Islāmī, 'al-Muḍārabah fĩ al- ‘Umlat,' vol. 1, 556.

68 Majma' al-Fiqh al-Islāmī, 'al-Muḍārabah fī al- ‘Umlat,' vol. 1, 556.
} 
Amalan Pertukaran Asing Konvensional:

Analisa Berdasarkan Perspektif Syariah

Islam mengharuskan lindung nilai dan FX Forward digunakan untuk tujuan tersebut. Namun tujuan ini tidak menyebabkan urus niaga FX Forward diharuskan pada pandangan syarak kerana urus niaga yang dilakukan itu menyalahi hukum syarak. Oleh sebab itu, Sheikh 'Alī al-Salūs mencadangkan agar difikirkan struktur alternatif bagi FX Forward. Sesetengah institusi perbankan Islam sudah menawarkan urus niaga yang memberikan kesan yang dengan FX Forward melalui jual beli komoditi. ${ }^{69}$

Institusi perbankan Islam juga menawarkan FX Forward patuh Syariah dengan menggunakan konsep wa'd. Ini menunjukkan terdapat alternatif lain bagi pihak yang ingin melakukan urus niaga FX Forward. Ia berbeza dengan FX Spot yang hanya terdapat satu sahaja struktur dalam pasaran pertukaran asing.

Kajian mendapati Akademi Fiqh Islam di bawah naungan Liga Dunia Muslim dalam persidangannya kali ke-5 pada tahun 1982 melalui resolusi no. 6/1 tentang al-'Umlah al-Waraqiyyah (Wang Kertas) telah membincangkan tentang urus niaga pertukaran mata wang secara bertangguh. Resolusi ini menetapkan bahawa tidak boleh menjual wang kertas yang sama jenis atau berlainan jenis daripada emas dan perak, atau selain emas dan perak secara bertangguh sama sekali. Maka tidak boleh menukar mata wang seperti Riyal Saudi dengan mata wang lain secara tafädul dan bertangguh tanpa qabd..$^{70}$ Dengan kata lain, resolusi ini mengharamkan urus niaga FX Forward yang melakukan pertukaran asing secara bertangguh.

Akademi Fiqh Islam Liga Dunia Muslim semasa persidangan kali ke-13 di Makkah pada 8 Februari 1992 membincangkan tentang perjanjian menjual mata wang dan mengeluarkan resolusi no. 1 tentang Bi Sya'n Mawdū' alMuwā'adah bi Bay' al- 'Umūlāt Ba'duhā bi Ba'd, Hal Yajūz An Yaqūm alMașrif aw al-Syarikah bi Tartīb 'Amaliyāt Syirā (Janji Dua Belah Pihak dalam Jual Beli Mata wang, Adakah dibenarkan Bank atau Syarikat Melakukan Transaksi Pembelian). Resolusi ini menyatakan jika kontrak pertukaran mata wang mensyaratkan serahan lewat kedua mata wang atau salah satu mata wang untuk diserahkan pada masa hadapan, maka kontrak ini tidak dibenarkan kerana syarat taqābuḍ sebagai syarat sempurna kontrak al-ṣarf tidak berlaku. ${ }^{71}$

69 Majma' al-Fiqh al-Islāmī, 'al-Muḍārabah fī al-‘Umlah,' vol. 1, 592.

70 Rābițah al-'Alām al-Islāmī, 'Bi Sya'n Mawdū' al-Muwā'adah bi Bay' al-'Umūlāt Ba'duhā bi Ba'd, Hal Yajūz An Yaqūm al-Mașrif aw al-Syarikah bi Tartīb 'Amaliyāt Syirā’ Mustaqbalī li Șālị̣ Aḥad al-'Umalā' bi Ṭalab Minh?,' laman sesawang Räbițah al-'Alām al-Islämī, http://www.themwl.org/ Fatwa/default. aspx?d=1\&cidi=132\&l=AR\&cid =10, dicapai 4 Februari 2016.

71 Rābiṭah al-'Alām al-Islāmī, 'Bi Sya’n Mawdū' al-Muwā'adah.' 
Akademi Fiqh Islam Antarabangsa OIC telah mengeluarkan resolusi bil. 102 (11/5) tentang al-Itjār fì al-'Umulāt (Perdagangan Mata Wang) dalam persidangan ke-11 di Manama, Bahrain pada 14-19 November 1998 juga mengharamkan pertukaran mata wang hadapan melalui FX Forward. Kedua pihak juga tidak dibenarkan melakukan pertukaran bertangguh di antara satu sama lain berdasarkan al-Quran, sunnah dan ijmak. Resolusi ini juga menyatakan transaksi riba dan perdagangan mata wang yang tidak mengikut hukum Syariah Islam adalah di antara sebab berlakunya krisis ekonomi yang menimpa sesetengah negara. ${ }^{72}$

AAOFI melalui Paramater Syariah no. 1 tentang al-Mutājarah al- 'Umulāt (Perdagangan Mata wang) mengharamkan urus niaga FX Forward kerana kedua pihak tidak melakukan qabd terhadap mata wang yang ditukarkan. Institusi kewangan Islam tidak dibenarkan melakukan urus niaga FX Forward walaupun untuk lindung nilai terhadap perubahan nilai mata wang pada masa hadapan. ${ }^{73}$

Dewan Syariah Nasional di Majelis Ulama Indonesia pula melalui fatwa no. 28/DSN-MUI/111/2002 tentang Jual Beli Mata Uang (al-Sharaf) mengatakan hukum urus niaga FX Forward adalah haram kerana harga yang dikontrakkan dan serahan pada hari hadapan. Sedangkan pada hari penyerahan mata wang belum pasti sama dengan nilai mata wang yang disepakati. ${ }^{74}$

Lembaga Syariah Al Rajhi Bank, Saudi Arabia melalui fatwa no. 195 dan Lembaga Syariah Bank Al Bilād, Saudi Arabia pula melalui Parameter no. 453 mengharamkan FX Forward kerana tidak mematuhi syarat al-ṣarf dan mengandungi unsur bay 'al-kalī’ bi al-kalī' (jual beli hutang dengan hutang) yang diharamkan oleh syarak. FX Forward ini juga tidak diharuskan walaupun digunakan untuk lindung nilai. ${ }^{75}$

72 Majma' al-Fiqh al-Islamī al-Dawlī, 'al-Itjar fī al-'Umulāt,' laman sesawang Majma' al-Fiqh al-Islamī al-Dawlī, http://www.iifa-aifi.org/2035,html dicapai 3 Februari 2016.

73 Hay'ah al-Muhāasabah, al-Ma 'āyir al-Syar 'iyyah, 5-6.

74 Dewan Syariah Nasional, 'Fatwa Dewan Syari'ah Nasional Nomor 28/DSN-MUI/ III/2002 Jual Beli Mata Uang (al-Sharf).'

75 Amānah al-Hay'ah al-Syar'iyyah, al-Dawābiḍ al-Mustakhlaṣah, 136. alMajmū'ah al-Syar'iyyah bi Mașrif al-Rājị̣̄̄, Qarārat al-Hay'ah al-Syar 'iyyah bi Maṣraf al-Rājiḥ̂̄, vol. 1 (Riyāẹ:Dār Kanuz Isyibiliya li Nasyr wa Tawzi‘, 2010), 29. 


\section{Pandangan Terpilih}

Berdasarkan hujah-hujah yang dikemukakan oleh oleh setiap golongan, penulis memilih pandangan majoriti ulama yang mengharamkan FX Forward kerana kelewatan penyerahan mata wang bagi kedua mata wang dalam urus niaga FX Forward menyalahi hadis-hadis Nabi SAW dan ijmak ulama yang menetapkan setiap pertukaran emas dan perak perlu yadan bi yadin atau bersegera. Selain itu, ulama kontemporari dan kebanyakan fatwa daripada majlis fatwa hanya mengharuskan kelewatan taqābud berlaku dalam FX Spot sahaja. Manakala tempoh serahan mata wang dalam FX Forward telah melebihi tempoh yang dibenarkan dalam FX Spot. Selain itu, kelewatan serahan kedua mata wang dalam FX Forward juga menyebabkan wujud unsur bay ' al-kalı’ bi al-kalı’' yang diharamkan oleh syarak.

\section{ANALISA FX SWAP BERDASARKAN PERSPEKTIF SYARIAH}

Kajian mendapati terdapat hanya satu pandangan dalam kalangan ulama kontemporari tentang FX Swap yang mengatakan urus niaga ini adalah haram kerana menyalahi Syariah. Pandangan ini dipegang oleh Sheikh 'Alī al-Salūs, ${ }^{76}$ Sheikh 'Abd al-Sattār Abū Ghuddah, ${ }^{77}$ Dr. Aḥmad Muḥy al-Dīn, ${ }^{78}$ Dr. 'Abd alBārī Misy'al, ${ }^{79}$ Dr. Mubārak bin Sulaymān, ${ }^{80}$ Bisyr Muḥammad Mūfiq Luṭî ${ }^{81}$ dan sebagainya.

FX Swap digunakan untuk mengurus keperluan mata wang asing di dalam sesebuah bank sama ada untuk memenuhi keperluan dana jangka pendek bagi pihak bank atau pihak pelanggan (bank yang lain). Contoh Bank A memerlukan mata wang Dolar Amerika dan dengan ingin menukarkannya dengan Ringgit Malaysia. Maka pihak bank bank akan membeli Ringgit Malaysia dan menjual Dolar Amerika pada kadar spot kepada Bank A. Kemudian pihak bank menjual kembali Dolar Amerika tersebut secara forward dengan kadar yang lebih lebih tinggi kepada Bank A. Perbezaan di antara dua harga ini adalah kadar faedah.

\footnotetext{
76 Majma' al-Fiqh al-Islāmī, 'al-Muḍārabah fĩ al-'Umlah,' vol. 1, 593.

77 Abū Ghuddah, Buhūth fì al-Mu' 'àmalāt, vol. 8, 111.

78 Aḥmad Muḥy al-Dīn, 'al-Muḍārabah fĩ al-'Umlah,' vol. 1, 458.

79 'Abd al-Bārī Misy'āl, 'Dawabiḍ Șarf al-‘Umulāt,' 5-6.

80 Mubārak bin Sulaymān bin Muhammad 'Alī Sulaymān, Ahkām al-Ta 'āmul fĩ alAswāq al-Māliyyah al-Mu 'āṣirah (Riyāọ: Dār Kunūz Isybīlìyā li Nasyr wa alTawzī', 2005), 1110.

81 Bisyr Muḥammad, al-Tadāwul al-Iliktarūn̄̄ li al- 'Umūlāt, Turuquh al-Dawlīyah wa Aḥkāmuh al-Syar 'iyyah ('Amman: Dār al-Nafā' is, 2009), 91.
} 
Sebenarnya urus niaga yang dilakukan ini ialah bank meminjam sejumlah mata wang tertentu dan menjual membayarnya kembali mata wang tersebut pada tarikh hadapan dengan harga yang lebih tinggi. Kadar tambahan ini adalah faedah atau riba yang diharamkan syarak. ${ }^{82}$

Jual beli yang dilakukan ini sebenarnya adalah berbentuk pinjaman. Bahkan dalam dunia FX Swap, mereka lebih menggunakan istilah pinjam berbanding jual beli kerana duit yang dipinjam akan dipulangkan kembali bersama nilai tambahan. Kontrak pinjaman yang disyaratkan jumlah bayaran tambahan melebihi jumlah pokok berdasarkan tempoh masa tertentu adalah jelas mengandungi elemen riba yang diharamkan syarak.

Walaupun pertukaran mata wang dalam FX Swap kelihatan terdiri daripada urus niaga pertukaran secara spot dan forward namun sebenarnya urus niaga ini dilakukan secara serentak melalui sistem urus niaga FX Swap. Dengan kata lain, bank meminjam (membeli) mata wang tertentu daripada pihak kedua dan pada masa yang sama memulangkan (menjual) kembali dengan tambahan nilai kepada pihak yang sama. Berdasarkan senario ini juga, wujud dua kontrak yang dilakukan dalam satu kontrak, iaitu kontrak pertukaran secara spot dan forward. Jual beli jenis ini tidak dibenarkan oleh Syariah kerana ia adalah bay'atayn fi bay'ah atau dua kontrak dalam satu kontrak yang diharamkan syarak. ${ }^{83}$

Berdasarkan kenyataan di atas, FX Swap terdiri daripada kontrak spot dan forward. Tiada isu Syariah jika jika berlaku taqābud terhadap kedua mata wang dalam kontrak pertama. Namun taqābud tidak berlaku dalam kontrak yang kedua. Perkara ini menyebabkan kontrak yang kedua adalah haram kerana melakukan pertukaran wang secara bertangguh dan ia termasuk di dalam kategori ribā al-nasī'ah dan bay 'al-dayn bi al-dayn yang diharamkan secara ijmak ulama.

Selain itu, pemateraian kontrak kedua telah disyaratkan dalam kontrak pertama iaitu kedua pihak akan membeli kembali mata wang yang dijual dalam kontrak pertama secara bertangguh. Syarat begini adalah haram mengikut pandangan syarak kerana menyalahi perintah Allah dan mengandungi unsur riba dan bay' al-dayn bi al-dayn. Syarat ini juga menyebabkan kontrak

\footnotetext{
82 Majma' al-Fiquh al-Islāmī, 'al-Muḍārabah fī al-'Umlah,' vol. 1, 593; 'Abd al-Bārī Misy'āl, 'Ḍawabị̣ Șarf al-'Umulāt,' 5-6; Abū Ghuddah, Buhūth fì al-Mu 'āmalāt, vol. 8,111 .

83 Aḥmad Muḥy al-Dīn, 'al-Muḍārabah fī al-'Umlah,' vol. 1, 458.
} 
pertama adalah rosak atau fas $\bar{a} d{ }^{84} \mathrm{Nabi}$ SAW melarang sebarang syarat yang bātil sebagaimana dalam hadis: ${ }^{85}$

$$
\text { ما كان من شر ط ليس في كتاب الله فهو باطل، و إن كان مائة شرط }
$$

"Syarat yang tidak didapati dalam al-Quran adalah batil, walaupun ia terdiri daripada seratus syarat."

Semasa kontrak kedua, kedua pihak melakukan pertukaran mata wang pada kadar forward dengan dengan tidak memiliki mata wang tersebut. Ini disebabkan mata wang tersebut masih belum diterima oleh kedua pihak. Dengan itu, urus niaga yang dilakukan adalah dilarang syarak kerana menjual mata wang tiada. Urus niaga FX Swap menyerupai bay' al- 'inah yang diharamkan iaitu menjual mata wang secara spot dan kemudian membeli kembali secara bertangguh dengan tambahan nilai. ${ }^{86}$

Pandangan golongan ini dipersetujui oleh AAOIFI melalui Paramater Syariah no. 1 tentang al-Mutājarah al-'Umulāt (Perdagangan Mata Wang) bahawa tidak dibenarkan melakukan pembelian dan penjualan secara selari atau serentak. Ini adalah ciri urus niaga FX Swap yang menghimpunkan jual beli mata wang pada kadar spot dan forward dalam satu masa. Parameter ini menyebut urus niaga FX Swap tidak diharuskan kerana mengandungi tiga faktor yang dilarang syarak.

Pertama, ketiadaan penyerahan dan penerimaan kedua mata wang yang dibeli dan dijual serta jual beli mata wang secara bertangguh. Kedua, pertukaran mata wang yang dilakukan mensyaratkan melakukan pertukaran mata wang yang lain. Ketiga, wujud perjanjian pertukaran untuk penyerahan pada masa hadapan di antara dua pihak yang bersifat mengikat dan perkara ini dilarang oleh syarak. ${ }^{87}$

FX Swap juga diputuskan haram oleh Dewan Syariah Nasional Majelis Ulama Indonesia (DSN-MUI) pada tahun 2002 melalui fatwa no. 28/ DSN-MUI/III/2002 Jual Beli Mata Uang (al-Sharf) kerana urus niaga ini

\footnotetext{
${ }^{84}$ Mubārak bin Sulaymān, Aḥkām al-Ta 'āmul, 1110.

85 Riwayat al-Bukhārī, Kitāb al-Buyū‘, Bāb Izā Isytaraț Syurūṭ fĩ al-Bay‘ Lā Tahilll, no. 2168 dan Muslim, Kitāb al-'Itq, Bāb Innamā al-Walā' liman A'taq, hadis no. 1504. Lihat al-Bukhārī, Șaḥịh al-Bukhārī, vol. 3, 73 dan Muslim, Șaḥịh Muslim, vol. 2, 1141.

86 'Abd al-Bārī Misy'āl, 'Dawabị̣ Șarf al-'Umulāt, 5-6; Bisyr Muḥammad, alTadāwul al-Iliktarūnī li al-'Umūlāt,' 91.

87 Hay'ah al-Muhāasabah, al-Ma'āyir al-Syar'iyyah, 8.
} 
mengandungi unsur spekulasi ${ }^{88}$ Lembaga Syariah Al Rajhi Saudi Arabia dan Lembaga Syariah Bank Al Bilad Saudi Arabia turut mengharamkan FX Swap kerana mengandungi elemen yang diharamkan syarak. ${ }^{89}$

\section{Pendapat Terpilih}

Berdasarkan hujah-hujah yang dikemukakan di atas jelas menunjukkan FX Swap adalah haram kerana mempunyai banyak elemen yang diharamkan syarak seperti tiada taqābud terhadap mata wang yang dijual beli, jual beli mata wang yang tiada dalam pegangan, syarat bātil untuk pemateraian kontrak kedua, bay 'atayn fi bay 'ah, pinjaman mata wang berasaskan riba dan sebagainya. Kesimpulannya, mekanisme urus niaga FX Swap ini adalah haram kerana menyalahi peraturan al-șarf dan peraturan syarak yang lain.

\section{KESIMPULAN}

Persoalan pertukaran asing tidak dibincangkan oleh ulama terdahulu kerana urus niaga ini baharu muncul pada zaman moden. Ulama kontemporari membincangkan persoalan urus niaga pertukaran asing dengan mendalam berpandukan perbincangan ulama terdahulu tentang konsep al-sarf. Ulama berbeza pandangan terhadap urus niaga FX Spot sehingga melahirkan perbezaan pandangan dalam kalangan ulama. Setelah mengkaji dan meneliti hujah-hujah setiap golongan, penulis mendapati pandangan majoriti ulama yang mengharuskan urus niaga FX Spot adalah lebih kuat, tepat dan sesuai untuk kemaslahatan manusia.

Isu Syariah utama dalam FX Spot ialah mekanisme qabd yang digunakan dalam urus niaga FX Spot. Hadis-hadis Nabi SAW dengan jelas menunjukkan qabd perlu dilakukan dengan segera sebelum kedua pihak berpisah daripada majlis akad. Majoriti ulama kontemporari berpandangan qabd di dalam hadis ini perlu ditentukan oleh penafsiran uruf perniagaan kerana syarak dan bahasa tidak memberikan penafsiran terhadap qabd. Mereka menganggap kelewatan qabd dalam FX Spot diterima sebagai penafsiran qabd dan ia tidak dapat dielakkan apabila memasuki pasaran pertukaran asing. Dengan itu, majoriti ulama berpandangan FX Spot adalah harus dan ia bersesuaian dengan syarak yang memudahkan urusan manusia.

\footnotetext{
88 Dewan Syariah Nasional, 'Fatwa Dewan Syari'ah Nasional Nomor 28/DSN-MUI/ III/2002 Jual Beli Mata Uang (al-Sharf).'

89 Majmū'ah al-Syar'iyyah, al-Dalīl al-Syar' '̄, 153; Amānah al-Hay'ah alSyar'iyyah, al-Ḍawābiț al-Mustakhlașah, 138.
} 
Manakala isu Syariah utama dalam FX Forward ialah kelewatan serahan kedua mata wang yang melebihi tarikh FX Spot seperti sebulan, 3 bulan, 6 bulan dan sebagainya. Majoriti ulama kontemporari menganggap tempoh kelewatan qabd dalam FX Forward tidak diterima sebagai qabd yang segera. Ia berbeza dengan qabd dalam FX Spot yang mendesak keperluannya. FX Forward juga digunakan untuk lindung nilai namun struktur FX Forward mempunyai elemen yang menyalahi peraturan Syariah. Justeru itu, majoriti ulama berpandangan bahawa FX Forward adalah haram kerana melanggar peraturan al-sarf yang ditetapkan oleh Syariah.

Ulama juga mengharamkan urus niaga FX Swap kerana mengandungi terlalu banyak isu yang menyalahi menyalahi peraturan al-șarf seperti tiada qabḍ bagi mata wang yang ditukarkan, penjualan mata wang yang tiada dalam pegangan, pensyaratan kontrak kedua dalam kontrak pertama, dua kontrak dalam satu kontrak, jual beli hutang dengan hutang dan sebagai.

Islam telah meletakkan peraturan al-sarf sebagai garis panduan dalam pertukaran asing. Dengan itu, semua pihak perlu memastikan urus niaga pertukaran asing yang dilakukan tidak mengandungi unsur riba atau perkara yang menyalahi syarak. Struktur FX Forward dan FX Swap patuh Syariah boleh dibentuk dengan menggunakan konsep wa' $d$, transaksi murābahah atau konsep Syariah lain yang bersesuaian. Kini kewujudan banyak institusi perbankan Islam menawarkan urus niaga pertukaran asing yang berlandaskan Syariah. Setiap urus niaga pertukaran asing patuh Syariah ini memberikan kesan ekonomi yang sama sebagaimana urus niaga pertukaran asing konvensional, namun bebas daripada riba dan larangan syarak.

\section{RUJUKAN}

'Abd al-Sattār Abū Ghuddah, Buhūth fì al-Mu'āmalāt wa al-Asālīb alMașrafìyah al-Islāmīyah, vol. 8 (Jeddah: Majmū'ah Dallah al-Barakah, 2007).

Aḥmad Muḥy al-Dīn Aḥmad, 'al-Muḍārabah fī al-'Umlah wa al-Wasā'il alMasyrū'ah li-Tajtanib Aḍrārahā al-Iqtișādīyah,' Majallah Majma ‘ alFiqh al-Islāmī, vol. 1/11 (1998).

al-'Aẓīm Ābādi, Muḥammad Asyraf bin Amīr, 'Awn al-Ma 'būd Syarh Sunan Abī Dāwud (Beirūt: Dār al-Kutub al-'Ilmiyyah, 1995).

al-Asy‘ath, Abū Dāwud Sulaymān, Sunan Abī Dāwud (Beirūt: al-Maktabah al-'Asriyah, t.t.).

al-Bukhārī, Muḥammad bin Ismāi 'il, Șaḥịh al-Bukhārī, ed. Muḥammad Z̄āhir bin Nāṣir al-Nāṣir (Beirūt: Dār al-Ṭūq al-Najāh, 2001). 
Amānah al-Hay'ah al-Syar'iyyah, al-Ḍawābị̣ al-Mustakhlaṣah min Qarārāt al-Hay'ah al-Syar'iyyah li Bank al-Bilād (Riyāḍ: Dār al-Mayman, 2013).

Badw̄î, Āṣim Aḥmad 'Āṭ̂yah, 'Aḥkam al-Ṣarf al-Ilikturūn̄̄ fī al-Fiqh alIslāmī', (Tesis sarjana, Kuliah Syariah dan Undang-Undang, Universiti Islam Gaza, Palestin, 2010).

Bank for International Settlements, Trennial Central Bank of Foreign Exchange and Derivatives Market Activity in 2001 (Basel: Bank for International Settlements, 2002).

Bank for International Settlements, Triennial Central Bank Survey Foreign Exchange Turnover in April 2013: Preliminary Global Results (Switzerland: Bank for International Settlements, 2013).

Bank Negara Malaysia Berhad, Resolusi Syariah dalam Kewangan Islam Edisi Kedua (Kuala Lumpur: Bank Negara Malaysia, 2010).

Bank Negara Malaysia Berhad, Bank Negara Malaysia dan Sistem Kewangan di Malaysia: Perubahan Sedekad (Kuala Lumpur: Bank Negara Malaysia, 1999).

al-Buhūtī, Manșur Ibn Yunūs Ibn Idrīs, Kasyf al-Qinā' 'an Matn al-Iqnā' (Beirūt: Dār al-Fikr, 1982).

Bisyr, Muhammad, al-Tadāwul al-Iliktarūn̄̄ li al-'Umūlāt, Turuquh alDawlīyah wa Ahkāmuh al-Syar 'iyyah ('Amman: Dār al-Nafā'is, 2009).

Cornelius Luca, Trading in the Global Currency Markets (New York: Prentice Hall, 2000).

Dewan Syariah Nasional, 'Fatwa Dewan Syari'ah Nasional Nomor 28/DSNMUI/III/2002 Jual Beli Mata Uang (al-Sharf),' laman sesawang Dewan Syariah Nasional-Majelis Ulama Indonesia, http:/www.dsnmui.or.id/ index.php?mact $=$ News, cntnt01,detail,0\&cntnt01articleid $=29 \&$ cntnt01o rigid $=59 \&$ cntnt01 detailtemplate $=$ Fatwa $\&$ cntnt 01 returnid $=15 \&$ cntnt 01 returnid=15, dicapai 1 Oktober 2016.

Fatḥ̄ Salīm Ziyād Ghazāl, Hukm al-Syar' fì al-Burșah ('Amman: Dār alWaddāḥ, 2008).

Grabbe, J. Orlin, International Financial Markets, ed. ke-3 (New Jersey: Prentice-Hall. Inc., 1996).

Hamad, Nazīh Kamal, 'al-Qabḍ al-Haqīīi wa al-Hukmī: Qawā'id wa Taṭbīqātuh min al-Fiqh al-Islāmī,' Majallah Majma ‘ al-Fiqh al-Islāmī, vol. 1/6 (1990).

Hay'ah al-Muḥāsabah wa al-Murāja'ah li al-Mu'assah al-Mālīyah alIslāmiyyah, al-Ma 'āyir al-Syar 'iyyah (Manama: Hay’ah al-Muhāāabah wa al-Murāja‘ah li al-Mu’assah al-Māliyyah al-Islāmiyyah, 2010), 
Amalan Pertukaran Asing Konvensional:

Analisa Berdasarkan Perspektif Syariah

Ibn Qudāmah 'Abd Allāh bin Aḥmad al-Muqaddasī, al-Mughnī li Ibn Qudāmah, vol. 4 (Qāhirah: Maktabah al-Qāhirah, 1968).

Ibn Taymīyah, Aḥmad bin 'Abd al-Halīm, Majmū'ah al-Fatāwā, vol. 20 (Madinah: Majma‘ al-Malik Fahd li Țibā'ah al-Muṣhaf al-Syarīf, 1995).

M. Levich, Richard, International Financial Markets, Price and Policies (Amerika Syarikat: McGraw-Hill, 1998).

Majma' al-Fiqh al-Islamī al-Dawlī, 'al-Itjar fī al-'Umulāt,' laman sesawang Majma ' al-Fiqh al-Islamī al-Dawlī, http://www.iifa-aifi.org/2035, html dicapai 3 Februari 2016.

Majma' al-Fiqh al-Islāmī, 'al-Muḍārabah fī al-'Umlah, al'Arḍ-al-Ta'qīb wa al-Munāqasyah,' dalam 'al-Muḍārabah fī al-'Umlat wa al-Wasā’il alMasyrū'ah li Tajtnanib Aḍrāhā al-Iqtișādīyah,' Majallah Majma' alFiqh al-Islāmī, vol. 1/11 (1998).

Majma' al-Fiqh al-Islāmī, 'al-Qabḍ: Șūrah wa bi Khāṣah al-Mustajiddah minhā wa Aḥkāmuhā,' laman sesawang Majma ‘ al-Fiqh al-Islamī, http://www. iifa-aifi.org/2035.html, dicapai 16 September 2016.

al-Majmū'ah al-Syar'iyyah bi Mașrif al-Rājiḥ̄, Qarārat al-Hay'ah alSyar 'iyyah bi Maṣraf al-Rājiḥ̄ (Riyāḍ: Dār Kanuz Isyibiliya li Nasyr wa Tawzi', 2010).

al-Majmū'ah al-Syar'iyyah bi Mașrif al-Rājih̄ị, Qarārāt al-Hay'ah alSyar 'iyyah bi Maṣraf al-Rājiḥ̄ (Riyāẹ: Dār Kunūz Isybīlīyā li Nasyr wa al-Tawzī', 2010).

al-Majmū'ah al-Syar'iyyah bi Mașrif al-Rājiḥ̄̄, al-Dalīl al-Syar'ī li alMuntajāt fi Dū'i Qarārāt al-Hay'ah al-Syar 'iyyah li Mașrif al-Rājiḥ̄ (Riyāḍ: Dār al-Kunūz Isybiliyā li al-Nasyr wa al-Tawzī', 2010).

Misy'āl, 'Abd al-Bārī, 'Ḍawabị̣ Șarf al-'Umulāt wa Badāil al-Taḥawwuṭ alMasyrū'ah fī al-Mu'assasah al-Māliyah al-Islāmiyyah,' (Kertas kerja, Mulataqā al-Khurtūm li al-Muntajāt al-Māliyyah al-Islāmiyyah, Markāz Bayān li Ḥandasah al-Māliyyah al-Islāmiyyah, 6-5 April 2012).

Mohidin Yahya, Tukaran Asing dan Pasaran Wang, Teori dan Amalan (Kuala Lumpur: Dewan Bahasa dan Pustaka, 1994).

Muhammad Akram Khan, 'Commodity Exchange and Stock Exchange in An Islamic Economy,' The American Journal of Islamic Social Science, vol.5/1 (1998): 101-102.

Muhammad Obaidullah, 'Financial Contracting in Currency Markets: An Islamic Evalution,' International Journal of Islamic Financial Services, vol. 3/3 (Oktober-Disember 2001). 
al-Nawāwī, Muḥy al-Dīn Yaḥyā bin Syarf, al-Majmū' Syarḥ al-Muhadhdhab (Damsyik: Dār al-Fikr, t.t.).

al-Nisābūrī, Muslim bin al-Hajjāj, Ṣaḥ̄ḥ Muslim (Beirūt: Dār Iḥyā’ al-Turāth al-'Arabī, t.t.).

Othman Yong, Pasaran dan Institusi Kewangan di Malaysia Teori dan Amalan (Kuala Lumpur: Dewan Bahasa dan Pustaka, 1993).

al-Qaraḍ̄āī, Yūsuf, 'Hawl (Fawrīyah al-Qabḍd) fī al-Bay' al-'Umulāt,' laman sesawang al-'Allāmah al-Qarad̄̄wī, http://www.qaradawi.net/new/allfatawa/6655-q-q, dicapai 12 Januari 2016.

al-Qurțūbī, Muḥammad bin Aḥmad bin Muḥammad, Bidāyah al-Mujtahid wa Nihāyah al-Muqtașid (Beirūt: Dār Ibn Hazm, 1999).

Rābitah al-'Alām al-Islāmī, 'Bi Sya’n Mawdū' al-Muwā'adah bi Bay' al'Umūlāt Ba'duhā bi Ba'd, Hal Yajūz An Yaqūm al-Mașrif aw alSyarikah bi Tartīb 'Amaliyāt Syirā’ Mustaqbalī li Șālị̣ Aḥad al-'Umalā’ bi Țalab Minh?,' laman sesawang Rābițah al-'Alām al-Islāmī, http:// www.themwl.org/ Fatwa/default.aspx? d=1\&cidi=132\&l=AR\&cid=10, dicapai 4 Februari 2016.

Sulaymān, Mubārak bin Sulaymān bin Muḥammad 'Alī, Aḥkām al-Ta'āmul fì al-Aswāq al-Māliyyah al-Mu'āṣirah (Riyāḍ: Dār Kunūz Isybīlīyā li Nasyr wa al-Tawzī', 2005).

al-Syarbīnī, Muḥammad Ibn al-Khātib, Mughnī al-Muḥtāj ilā Ma 'rifah Ma 'ān̄̄ Alfāz al-Minhāj (Beirūt: Dār al-Kutub al-'Ilmiyyah, 1994).

al-Syubaylī, Yūsuf bin 'Abd Allāh, 'al-Khadamāt al-Mașrafiyyah li-Istithmār Amwāl al-'Umalā’ wa Aḥkāmuhā fì al-Fiqh al-Islāmī,' (Tesis kedoktoran, Jabatan Fiqh Perbandingan, al-Ma'had al-'Ālī li al-Qaḍā', Riyāḍ, 2002).

Walsmsley, Julian, The Foreign Exchange and Money Markets Guide, ed. ke-2 (Kanada: John Wiley \& Sons, Inc., 2000). 